\title{
Wound-healing Gene Family Expression Differences Between Fetal and Foreskin Cells Used for Bioengineered Skin Substitutes
}

\author{
*Nathalie Hirt-Burri, $\uparrow+$ Corinne Scaletta, §Stefan Gerber, IIDominique P. Pioletti, \\ and $\dagger \neq$ Lee Ann Applegate
}

\begin{abstract}
*Department of Pediatric Surgery, University Hospital; $†$ Orthopedic Cell Therapy Unit, University Hospital; $\ddagger$ Hôpital Orthopédique de la Suisse Romande (HORS); \$Department of Gynecology and Obstetrics, University Hospital; and IL Laboratoire de Biomécanique en Orthopédie (EPFL-HORS), Institut de Biomécanique Translationnelle, Ecole Polytechnique Fédérale de Lausanne, Lausanne, Switzerland
\end{abstract}

\begin{abstract}
For tissue engineering, several cell types and tissues have been proposed as starting material. Allogenic skin products available for therapeutic usage are mostly developed with cell culture and with foreskin tissue of young individuals. Fetal skin cells offer a valuable solution for effective and safe tissue engineering for wounds due to their rapid growth and simple cell culture. By selecting families of genes that have been reported to be implicated in wound repair and particularly for scarless fetal wound healing including transforming growth factor-beta (TGF- $\beta$ ) superfamily, extracellular matrix, and nerve/ angiogenesis growth factors, we have analyzed differences in their expression between fetal skin and foreskin cells, and the same passages. Of the five TGF- $\beta$ superfamily
\end{abstract}

genes analyzed by real-time reverse transcriptionpolymerase chain reaction, three were found to be significantly different with sixfold up-regulated for TGF- $\beta 2$, and 3.8-fold for BMP-6 in fetal cells, whereas GDF-10 was 11.8 -fold down-regulated. For nerve growth factors, midkine was 36-fold down-regulated in fetal cells, and pleiotrophin was 4.76-fold up-regulated. We propose that fetal cells present technical and therapeutic advantages compared to foreskin cells for effective cell-based therapy for wound management, and overall differences in gene expression could contribute to the degree of efficiency seen in clinical use with these cells. Key Words: Cell banking-Cell culture-Fetal skin cells-Collagen scaffolds-Skin tissue engineering-TGF- $\beta$.
One of the major challenges of assuring increasing patients benefiting from tissue engineering in the future is the optimization of the choice of cell type and their isolation and proliferation. Equally important is the delivery system of chosen cells and their interaction with scaffolds to create a threedimensional tissue. Although increasing models for all types of tissues have been proposed which are related to the increased availability of cell sources and new biomaterials, it is in the field of cutaneous replacement that clinical applications have rapidly

\footnotetext{
doi:10.1111/j.1525-1594.2008.00578.x
}

Received February 2007; revised September 2007.

Address correspondence and reprint requests to Dr. Lee Ann Laurent-Applegate, Orthopedic Cell Therapy Unit, University Hospital, CHUV, PAV 03, Rm. 121, 1011 Lausanne, Switzerland. E-mail: Lee.Laurent-Applegate@chuv.ch advanced for different skin cell/tissue origins. Several cell types and tissues have been proposed as starting material for elaborate tissue engineering processing including autologous skin cells, adult stem cells, bone marrow, embryonic stem cells, cadaver skin, acellular dermis, de-epidermized dermis, allogenous full-thickness skin substitutes, xenografts, placenta, and amniotic fluid (1-6) (Table 1A). Their clinical uses have extended significantly for a wide variety of indications including burns, acute and chronic wounds, skin loss, surgical wounds, and bullous diseases (7). Technically, cellbased therapies should be relatively simple with respect to tissue collection, cell culture, cell expansion, and storage. Allogeneic-based therapies would provide a major advantage for availability when necessary. Therapeutically, cell-based therapies should have high wound-healing potential, no 
TABLE 1. Biological products and their composition

\begin{tabular}{|c|c|c|c|}
\hline \multicolumn{4}{|l|}{ A. Autologous products } \\
\hline Product & Cell types & Advantages & Disadvantages \\
\hline $\begin{array}{l}\text { Epicel } \\
\text { Genzyme Biosurgery, Cambridge, MA, USA }\end{array}$ & \multirow{7}{*}{ Keratinocytes } & \multirow{12}{*}{ Small and large surfaces } & \multirow{7}{*}{$\begin{array}{l}\text { Patient biopsy necessary } \\
\text { Several weeks delay } \\
\text { Complicated cell culture } \\
\text { Blistering during heating } \\
\text { Fragile }\end{array}$} \\
\hline $\begin{array}{l}\text { Laserskin } \\
\text { Fidia Advanced Blopolymers. Padua, Italy }\end{array}$ & & & \\
\hline $\begin{array}{l}\text { AcuDress } \\
\text { DFB Pharmaceulicals, Fort Worth, TX, USA }\end{array}$ & & & \\
\hline $\begin{array}{l}\text { Bioseed } \\
\text { BioTissue Technologies, Freiburg, Germany }\end{array}$ & & & \\
\hline $\begin{array}{l}\text { Autoderm } \\
\text { XCELLentis, Gent, Belgium }\end{array}$ & & & \\
\hline $\begin{array}{l}\text { MySkin } \\
\text { CellTran, Ltd., Sheffield, UK }\end{array}$ & & & \\
\hline $\begin{array}{l}\text { Epibase } \\
\text { Genévrier Lab., Sophia-Antipolis, Nice, France }\end{array}$ & & & \\
\hline $\begin{array}{l}\text { Epidex } \\
\text { Euroderm, Leipzig, Germany }\end{array}$ & $\begin{array}{l}\text { Hair follicle } \\
\text { Keratocytes }\end{array}$ & & $\begin{array}{l}\text { Several weeks delay } \\
\text { Complicated cell culture }\end{array}$ \\
\hline $\begin{array}{l}\text { HC Implants } \\
\text { Leiden, Netherlands }\end{array}$ & \multirow{2}{*}{ Fibroblasts } & & \multirow[b]{2}{*}{$\begin{array}{l}\text { Patient biopsy necessary } \\
\text { Several weeks delay }\end{array}$} \\
\hline $\begin{array}{l}\text { Hyalograft 3D } \\
\text { Fidia Advanced Biopolymers }\end{array}$ & & & \\
\hline $\begin{array}{l}\text { Autologous Grafting } \\
\text { Karocell Tissue Engineering } \\
\text { Stockholm, Sweden }\end{array}$ & Keratinocytes/fibroblasts & & $\begin{array}{l}\text { Patient biopsy necessary } \\
\text { Several weeks delay } \\
\text { Complicated cell culture }\end{array}$ \\
\hline $\begin{array}{l}\text { Karoskin } \\
\text { Karocell Tissue Engineering }\end{array}$ & Accelular cadaver dermis for carrier & & Donor screening difficulties \\
\hline \multicolumn{4}{|l|}{ B. Allogenous products } \\
\hline Product & Cell types & Advantages & Disadvantages \\
\hline $\begin{array}{l}\text { Cadaver skin } \\
\text { Nonprofit skin banks }\end{array}$ & $\begin{array}{l}\text { Intact skin either: cryopreserved, } \\
\text { lyophilized, glycerolized }\end{array}$ & \multirow{8}{*}{$\begin{array}{l}\text { Immediately available } \\
\text { Small and large surface }\end{array}$} & \multirow{5}{*}{$\begin{array}{l}\text { Only for cover } \\
\text { Secondary grafting necessary } \\
\text { Donor screening difficulties } \\
\text { Multiple donors }\end{array}$} \\
\hline $\begin{array}{l}\text { Alloderm } \\
\text { LifeCell, Woodlands, TX, USA }\end{array}$ & Acellular cadaver dermis & & \\
\hline $\begin{array}{l}\text { Karoskin } \\
\text { Karoderm } \\
\text { Karocell Tissue Engineering }\end{array}$ & $\begin{array}{l}\text { Cadaver skin } \\
\text { Acellular cadaver dermis }\end{array}$ & & \\
\hline $\begin{array}{l}\text { EZDerm } \\
\text { Brennen Medical, St. Paul, MN, USA }\end{array}$ & Porcine xenograft & & \\
\hline $\begin{array}{l}\text { Oasis } \\
\text { Healthpoint Ltd., Fort Worth, TX, USA }\end{array}$ & $\begin{array}{l}\text { Porcine xenograft } \\
\text { Small intestine mucosa }\end{array}$ & & \\
\hline $\begin{array}{l}\text { Dermagraft } \\
\text { Smith and Nephew, London, UK }\end{array}$ & Foreskin fibroblasts & & \multirow[t]{3}{*}{$\begin{array}{l}\text { Multiple donors } \\
\text { Only for cover } \\
\text { Secondary grafting necessary }\end{array}$} \\
\hline $\begin{array}{l}\text { Trancyte } \\
\text { Smith and Nephew }\end{array}$ & Foreskin fibroblasts & & \\
\hline $\begin{array}{l}\text { TransDerm } \\
\text { XCELLentis, Gent, Belgium }\end{array}$ & Donor keratinocytes & & \\
\hline $\begin{array}{l}\text { Apligraft } \\
\text { Organogenesis, Canton, MA, USA }\end{array}$ & $\begin{array}{l}\text { Foreskin fibroblasts } \\
\text { Foreskin keratinocytes }\end{array}$ & \multirow{2}{*}{$\begin{array}{l}\text { Immediately available } \\
\text { Small surfaces }\end{array}$} & \multirow{5}{*}{$\begin{array}{l}\text { Multiple donors } \\
\text { Complicated cell culture } \\
\text { Secondary grafting usually } \\
\text { necessary }\end{array}$} \\
\hline $\begin{array}{l}\text { OrCellÆ } \\
\text { Ortec Int., New York, NY, USA }\end{array}$ & $\begin{array}{l}\text { Foreskin fibroblasts } \\
\text { Foreskin keratinocytes }\end{array}$ & & \\
\hline $\begin{array}{l}\text { Lyphoderm } \\
\text { XCELLentis, Gent, Belgium }\end{array}$ & $\begin{array}{l}\text { Neonatal keratinocytes } \\
\text { Lyophilized }\end{array}$ & \multirow{3}{*}{$\begin{array}{l}\text { Immediately available } \\
\text { Longer shelf life }\end{array}$} & \\
\hline $\begin{array}{l}\text { Cryoceal } \\
\text { XCELLentis, Gent, Belgium }\end{array}$ & $\begin{array}{l}\text { Donor keratinocytes } \\
\text { Cryopreserved }\end{array}$ & & \\
\hline $\begin{array}{l}\text { Allox } \\
\text { DFB Pharmaceuticals, Fort Worth, TX, USA }\end{array}$ & $\begin{array}{l}\text { Foreskin fibroblasts } \\
\text { Foreskin keratinocytes } \\
\text { Spray }\end{array}$ & & \\
\hline
\end{tabular}


immunological-induced reactions, and no proinflammatory properties.

Until now, the majority of allogenous skin products that have been developed with cell culture are with donor foreskin tissue cells. The dermal fibroblasts and keratinocytes from foreskin cells have been used in products such as Dermagraft, TransCyte, and Apligraft, and all clinical data show that these products alone are not capable of full wound closure, but are used for wound cover while waiting for split or mesh grafting (Table 1B) (1,7-9). When fetal skin fibroblasts are used alone in similar delivery systems (native collagen), we have shown that no other surgical means or grafting techniques are necessary for burns, and acute and chronic wounds $(10,11)$. Therefore, the limitations of actual practice may be more in relation to the lower woundhealing capacities of chosen cell types, which have been for the most part foreskin fibroblasts and keratinocytes.

Fetal skin cells, more specifically fetal dermal fibroblasts, offer an ideal solution for effective and safe tissue engineering for wounds of all nature for several reasons including: (i) cell expansion capacity from one organ donation; (ii) minimal cell growth requirements; (iii) adaptation to biomaterials for delivery; and (iv) wound-healing capacity (Fig. 1).
First, fetal skin dermal fibroblasts have extensive expansion possibilities as it requires only one organ donation $\left(1-4 \mathrm{~cm}^{2}\right.$ tissue) to create enough frozen cells to produce a bank capable of making over 270 million fetal skin constructs $(9 \times 12 \mathrm{~cm})$. Second, cell culture requirements are minimal compared to stem or mesenchymal cell types. As the fetal skin dermal fibroblasts are already differentiated and do not need to be directed or altered, the vast number of additional growth factors normally necessary are not needed for cell culture and expansion. Third, fetal cells, unlike neonatal, young, or adult cells, adapt particularly well to biomaterials, allowing efficient and simple delivery to the patient. In our laboratory and in others, it has been shown that cells from donors (neonatal to adult) are not capable of efficient integration into various biomaterials, such as chitosan, and would not support cell attachment and cell growth resulting in toxicity to cells (12). $\mathrm{Ng}$ et al. (12) have emphasized that physical characteristics of scaffolds such as porosity and mechanical stability are important for withstanding cell contraction forces and assuring a homogenous distribution of cells throughout the scaffold. We have seen that fetal cells adapt well to various biomaterials (10). For processing of a final product for clinical delivery, both the homologous distribution and the

\section{Simple Preparation and Application}

\section{Cryopreserved cell bank \\ $-165^{\circ} \mathrm{C}(\sim 2,400 \mathrm{Vials}, \mathrm{MCB})$}

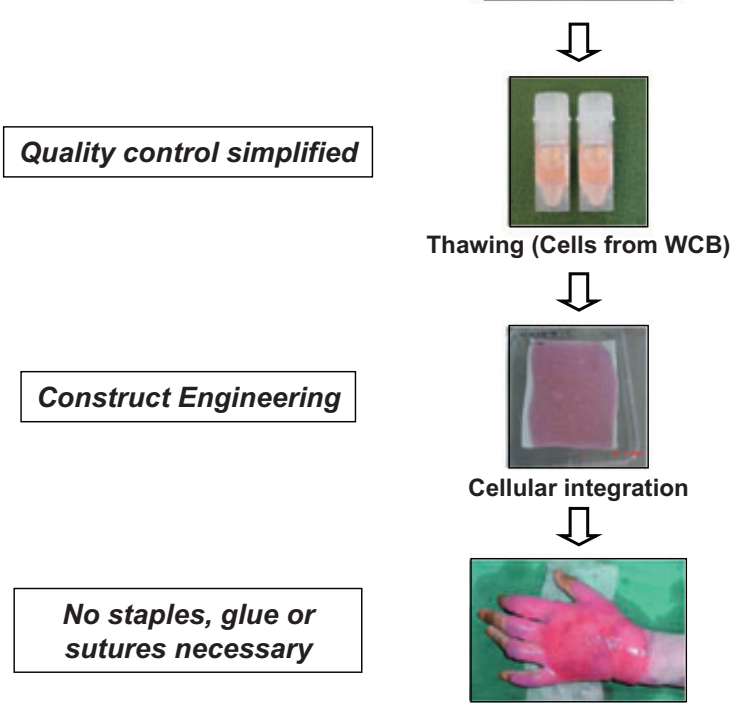

Flexible biological construct
FIG. 1. Simple, rapid, and secure bioengineered fetal skin for clinical use. With one organ donation of $1-4 \mathrm{~cm}^{2}$ of skin, it is possible to establish a fetal skin cell bank (Master Cell Bank, MCB or 2400 vials) which can produce "ready-touse" frozen aliquots of cells (Working Cell Bank vials that are thoroughly screened) that are evenly pipetted onto collagen matrix. Only $48 \mathrm{~h}$ is necessary to prepare fetal skin constructs when using cells from the frozen bank due to their rapid integration into the collagen matrix, and no staples, glue, or sutures are necessary for patient treatment. 
rapidity of development of the final product are major significant advantages. When long culture periods are necessary as for autologous grafting or for the commercially available skin products, to date there is a nonnegligible increased risk for contamination. It is also important to have a process that is consistent and easily repeated. By developing consistent cell banks with fetal dermal fibroblasts, many of the risk factors can be eliminated for bringing safe and effective human cell-based therapies to the bedside.

Most importantly, the wound-healing capacity seen with simplified cultured fetal skin dermal fibroblasts was of excellent quality for deep secondand third-degree burns, with little hypertrophy, no retraction, or inflammation of new skin (10). Overall, many difficulties of tissue engineering such as immunologic rejection, low growth capacity, and matrix compatibility could be reduced with fetal cells.

Differences in gene families, known to have an impact in the complex process of wound healing, between fetal skin cells and other cell types already therapeutically used in humans for several years could be of importance. Molecular analysis of wound healing has largely been devoted to cytokines, and most particularly those of the transforming growth factor (TGF) family and their role in manipulating cutaneous wound healing and scar formation (13). It has been suggested that scarless wound healing in fetal skin at early gestation is a result of the unique cytokine or growth factor profile $(14,15)$. Of these, TGF-beta (TGF- $\beta$ ) has been most widely studied as it is implicated in the transition between scarless healing and repair with scar formation (16).

We wished to look at possible differences in genes of the TGF- $\beta$ superfamily, and those genes involved in nerve/angiogenesis and extracellular matrix formation, known to have a major impact in wound healing, between foreskin tissue fibroblasts, that are widely used for biological skin products, and fetal skin dermal fibroblasts. These two cell types are possible for comparison with the same technical specifications (media requirements and culture time) as their large upscaling (cell banks) processing is accomplished in the same manner. As fetal skin dermal fibroblasts, at the age and passages used in bioengineered skin, have been shown to be efficient in total skin repair for burns and wounds, we wished to look at possible unique cellular and molecular characteristics of fetal fibroblasts which could contribute to the overall observed skin repair seen in clinical studies to date.

\section{MATERIALS AND METHODS}

\section{Skin biopsies and cell culture}

Cell lines established in the University Department of Obstetrics in Lausanne from fetal skin were used in these studies. Fetal skin biopsies (fetal 1-3, 14 weeks of gestation; fetal 4 and 5, 16 weeks of gestation) were obtained after pregnancy termination with informed consent and approval from the local Medical School Ethics Committee (fetal skin is considered to be an organ donation under Swiss law up to this phase of gestation). Neonatal foreskin tissue was obtained in the Department of Pediatric Surgery in Lausanne University Hospital.

Skin biopsies were dissected into three independent sections and then into $<0.5 \mathrm{~mm}^{3}$ fragments and grown in Dulbecco's modified Eagle's medium (DMEM) (Gibco, Grand Island, NY, USA) supplemented with $10 \%$ fetal bovine serum (FBS, Hyclone, Logan, UT, USA) and glutamine (Sigma, St. Louis, MO, USA). Cell outgrowth was allowed to $70 \%$ confluency, and cells were frozen in liquid nitrogen for long-term storage (15-20 units). Cells were used for experimentation between passages 2 and 6 , and were grown at $37^{\circ} \mathrm{C}$ in a humidified atmosphere of $95 \%$ air $/ 5 \% \mathrm{CO}_{2}$.

Consistent cell banks were established for one of each tissues (fetal 1 and foreskin) on a large scale for comparison. From one original $1-4 \mathrm{~cm}^{2}$ biopsy, 100 $6 \mathrm{~cm}$ plates were seeded with whole tissue fragments $\sim 4$ per plate $\left(<0.5 \mathrm{~mm}^{3}\right)$. These fragments were grown without any external growth factors. When cell growth advanced after approximately 1 week for fetal tissue, and 2-3 weeks for foreskin tissue, dishes of tissue and cells were trypsinized ( $0.25 \%$ trypsin $-0.1 \%$ ethylenediaminetetraacetic acid). At this point, 90 plates were frozen into individual units in liquid nitrogen. Cells were centrifuged at $2000 \times g$ for $15 \mathrm{~min}$, and resuspended in a freezing solution of DMEM $(5 \mathrm{~mL})+$ FBS (4 mL) + DMSO (1 mL, Fluka, St. Louis, MO, USA) and frozen in $1 \mathrm{~mL}$ aliquots $\left(1 \times 10^{7}\right.$ cells $)$ at $-80^{\circ} \mathrm{C}$ in Nalgene Cryo $1^{\circ} \mathrm{C}$ Freezing Containers (Nalgene, Hereford, UK) to achieve $\mathrm{a}-1^{\circ} \mathrm{C} / \mathrm{min}$ rate of cooling and freezing curve. After $24 \mathrm{~h}$, cells were transferred to liquid nitrogen for longer storage. Ten plates were amplified to 200 plates for fetal cells (1:20 dilution) and 100 plates for foreskin (1:10 dilution); 190 units were for the secondary frozen stock. These stocks can be subsequently amplified to create a cell bank destined for tissue-engineered skin constructs.

\section{RNA extraction and real-time reverse transcription-polymerase chain reaction (RT-PCR)}

Total RNA was isolated from cultured fetal and foreskin cells at passage 3 using the NucleoSpin, 
RNA II kit (Macherey-Nagel, Düren, Germany) as described by the manufacturer. The concentration and purity of each sample were assessed by absorbance at $260 \mathrm{~nm}$ and by the $260 / 280 \mathrm{~nm}$ ratio, respectively.

One microgram of total RNA was reverse transcribed using the 50 units of StratScript reverse transcriptase enzyme (Stratagene, San Diego, CA, USA) in a volume of $50 \mu \mathrm{L}$ containing $1 \times$ first-strand buffer (Stratagene), $3 \mu \mathrm{L}$ of random primers $(100 \mathrm{ng} / \mu \mathrm{L})$ (Promega, Madison, WI, USA), 40 units of RNasin (Promega), and $2 \mu \mathrm{L}$ of dNTP mix $100 \mathrm{mM}$ (Promega) as described by the manufacturer. The thermocycler Biometra T-1 (Biometra Biomedizinische Analytik GmbH, Göttingen, Germany) was programmed as follows: $25^{\circ} \mathrm{C}, 10 \mathrm{~min} ; 37^{\circ} \mathrm{C}, 60 \mathrm{~min}$; and $90^{\circ} \mathrm{C}, 5 \mathrm{~min}$.

Real-time RT-PCR using $160 \mathrm{ng}$ of cDNA was performed with ABI Prism 7000 Sequence Detection System (Applied Biosystems, Foster City, CA, USA). We measured the gene expression using alreadydesigned primers and probes by TaqMan Gene Expression Assays (Applied Biosystems) of midkine (MDK or neurite growth-promoting factor 2 [NEGF2]), pleiotrophin (PTN or heparin-binding growth factor 8, NEGF1), TGF- $\beta 1$, TGF- $\beta 2$, TGF- $\beta 3$, growth differentiation factor 10 (GDF-10 or BMP3B), laminin $\beta-1$ (LAMb1), dermatopontin (DPT), bone morphogenic protein 6 (BMP6), and $\beta$-actin (Table 2).

PCR reactions were performed in $25 \mu \mathrm{L}: 11.25 \mu \mathrm{L}$ of cDNA sample, 12.5 TaqMan Universal Master Mix (Applied Biosystems), and 1.25 of already-designed primers and probes by TaqMan Gene Expression Assays. Thermal cycle conditions were $50^{\circ} \mathrm{C}, 2 \mathrm{~min}$; $95^{\circ} \mathrm{C}, 10 \mathrm{~min}$, then 50 cycles at $95^{\circ} \mathrm{C}, 15 \mathrm{~s} ; 60^{\circ} \mathrm{C}, 1 \mathrm{~min}$. Relative gene expression was analyzed with the $2^{-\Delta \Delta \mathrm{CT}}$ method and normalized to $\beta$-actin gene. Measurements were performed in triplicates and reported as fold difference normalized with the fetal cells and associated standard deviation of the mean. Data were analyzed with a one-sided $t$-test, and differences were considered significant when $P<0.05$.

\section{RESULTS}

\section{Cell banking of fetal skin and foreskin tissue cells}

Cell banks were prepared from one fetal skin tissue and one foreskin tissue using the same process but with some minor differences. The fetal cells could be easily passaged with a dilution at 1:20 to 1:30, whereas the foreskin cells remained with the same growth characteristics when the dilution was 1:10. During the same time frame, this had an impact on the number of vials that could be frozen in the final cell bank for the two tissues. Fetal cell banks could easily be double to triple of that for the foreskin cell banks.

\section{Real-time RT-PCR expression for TGF- $\beta$ superfamily, nerve/angiogenesis factor, and ECM genes: Differences between fetal skin and foreskin tissue cells}

Out of the five TGF- $\beta$ superfamily genes tested, three were differently expressed between fetal skin and foreskin tissue cells (Fig. 2A). Expression was considered significant when more than a twofold difference was seen from the normalized value of the RT-PCR. There were no differences seen for TGF- $\beta 1$ $(P=0.063)$ and TGF- $\beta 3(P=0.734)$. For TGF- $\beta 2$, there was a $6.05(P=0.000003)$ fourfold difference with foreskin tissue cells having lower expression. In the BMPs, BMP6 was seen to have almost $3.8(P=$ $0.001)$ times less expression in foreskin tissue, and GDF-10 (BMP3B) was almost $11.8 \quad(P=0.0008)$ times less expressed in fetal skin cells (Fig. 2B,C). For nerve/angiogenesis factors, PTN was $4.76(P=$ $0.00000008)$ more pronounced in fetal skin cells, but MDK was about $36.4(P=0.01)$ times less expressed in fetal tissue cells (Fig. 2D,E). Neither of the two ECM genes (DPT or LAMb1) was seen to be significantly higher in fetal skin cells than foreskin tissue (Fig. 2F,G).

\section{Real-time RT-PCR expression for TGF- $\beta 1,-\beta 2$, and $-\beta 3$ isoform genes and ratios in fetal skin at 14 and 16 weeks gestation}

Relative gene expression for the isoforms of TGF- $\beta$ was measured in five different fetal tissues available covering different gestational ages to look at TGF- $\beta$ isoform ratios. Relative gene expression is based on the number of cycles for real-time RT-PCR to show relative gene expression differences between the three TGF- $\beta$ isoforms. No significant difference was seen for gene expression for five different donors with gestational age of 14 or 16 weeks $(P=0.233$ for TGF- $\beta 1, P=0.210$ for TGF- $\beta 2$, and $P=0.982$ for TGF- $\beta 3$ ). There was much more TGF- $\beta 1$ gene expression seen in fetal skin than for either of TGF- $\beta 2$ and TGF- $\beta 3$. The ratio of TGF- $\beta 1$ to TGF- $\beta 3$ is $21.47 \pm 1.98$, whereas TGF- $\beta 1$ to TGF- $\beta 2$ is $7.24 \pm 0.92$ (Fig. 3).

\section{DISCUSSION}

We have described herein that there are significant differences in the cell types that are used for biological skin substitutes. We have expanded cells from both fetal and foreskin tissue into large cell banks 


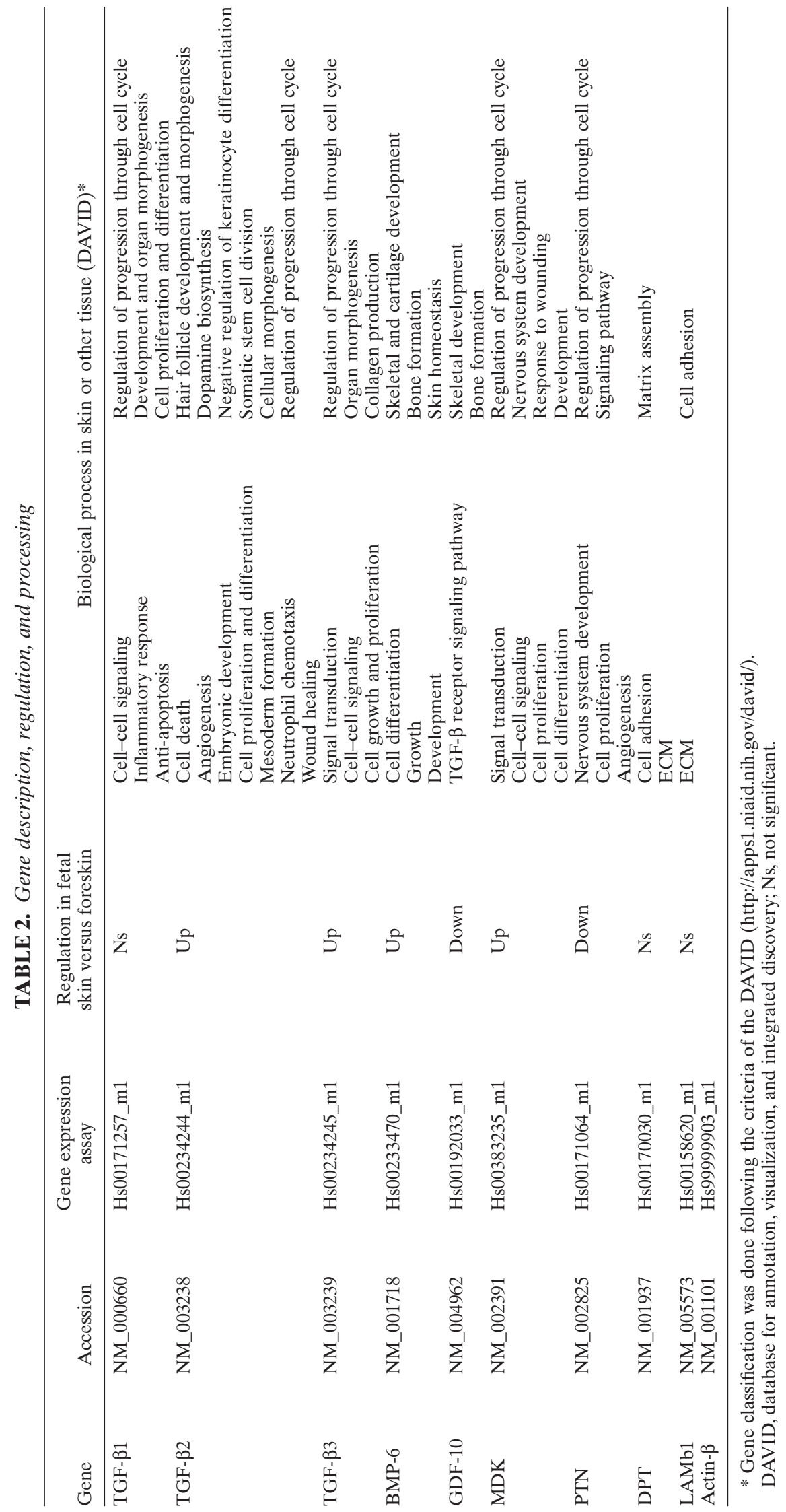




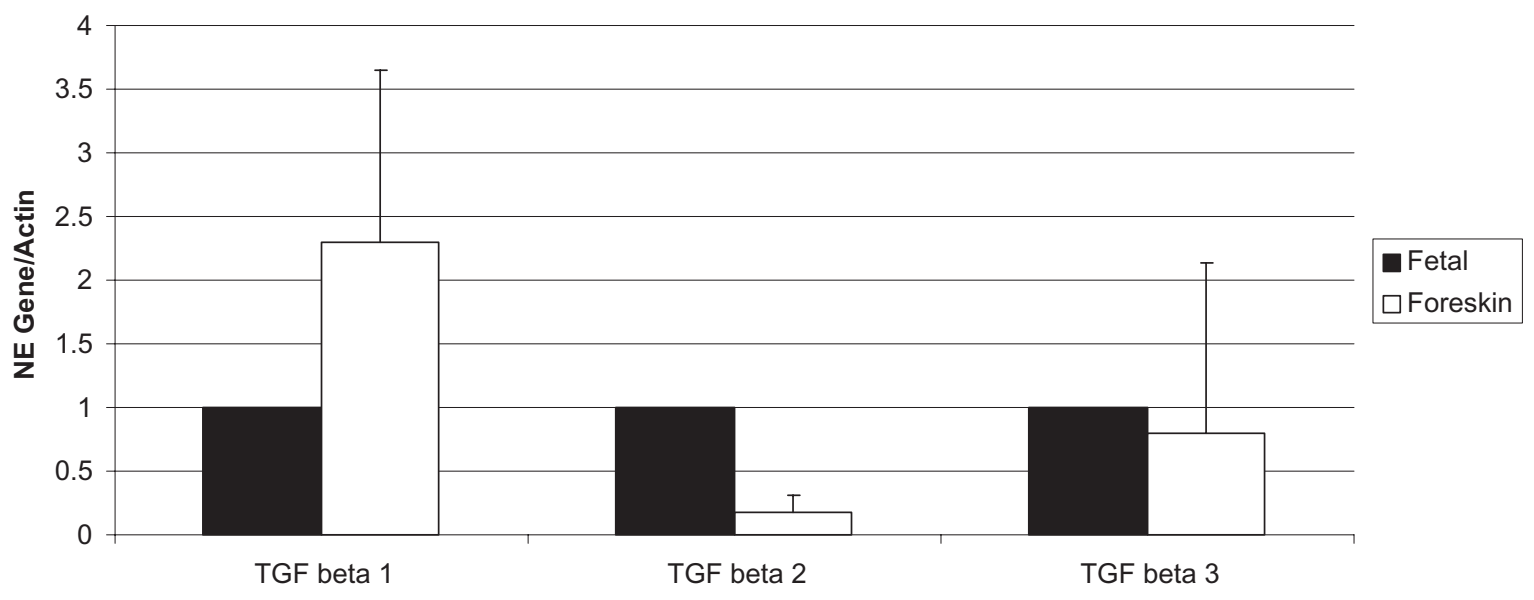

B
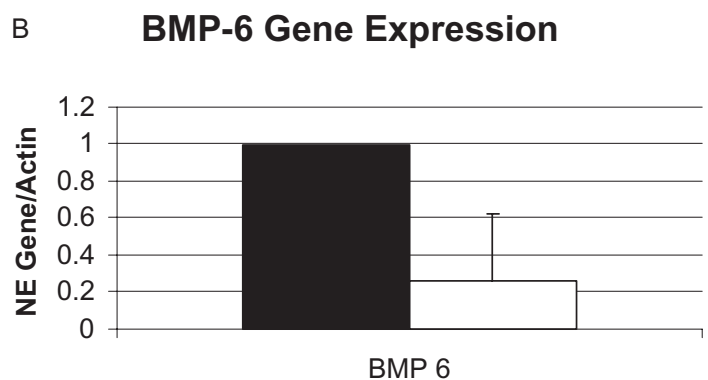

D
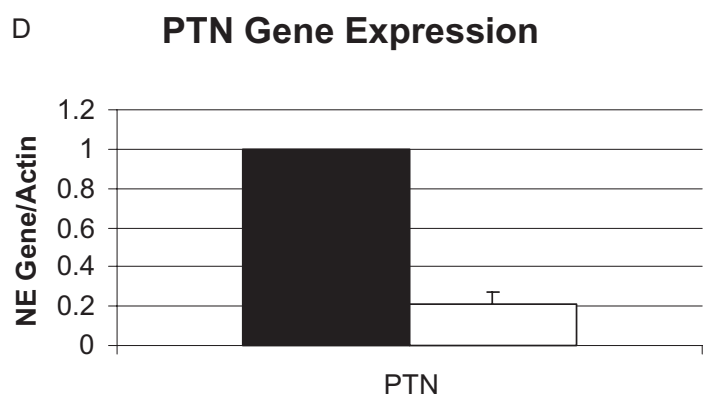

F
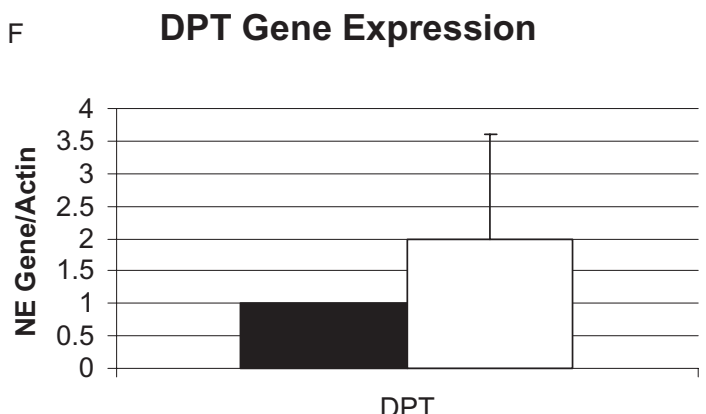

C GDF 10 Gene Expression

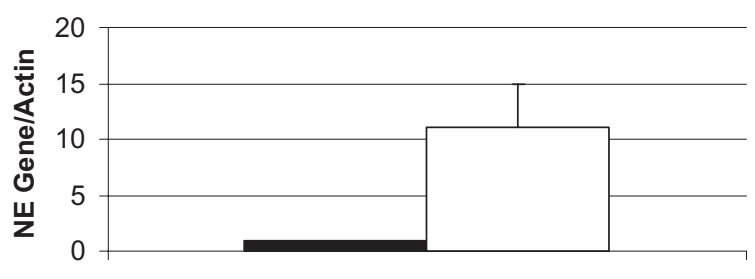

GDF 10

E MDK Gene Expression

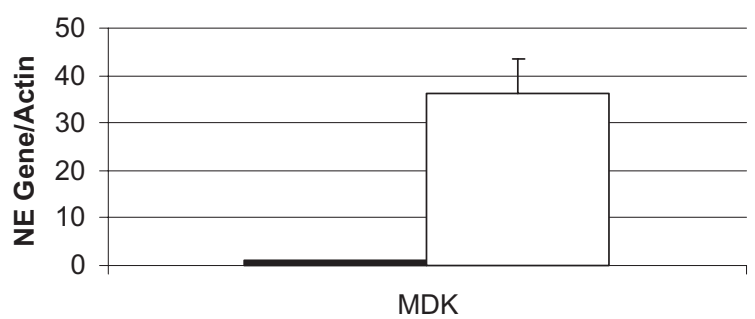

G LAMb1 Gene Expression

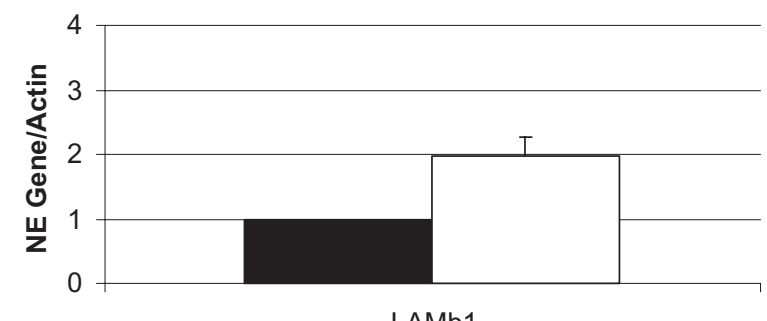

LAMb1

FIG. 2. Real-time PCR results for TGF- $\beta$ superfamily, ECM, and nerve/angiogenic genes for fetal skin and foreskin tissue cells from expanded cell banks. Gene expression was normalized to actin and expressed as a relative value of fetal skin for (A) TGF- $\beta 1, \beta 2, \beta 3$; (B) BMP-6; (C) GDF-10; (D) PTN; (E) MDK; (F) DPT; and (G) LAMb1. Expression was significant when a twofold difference was seen from the normalized value. Measurements were performed in triplicate. 


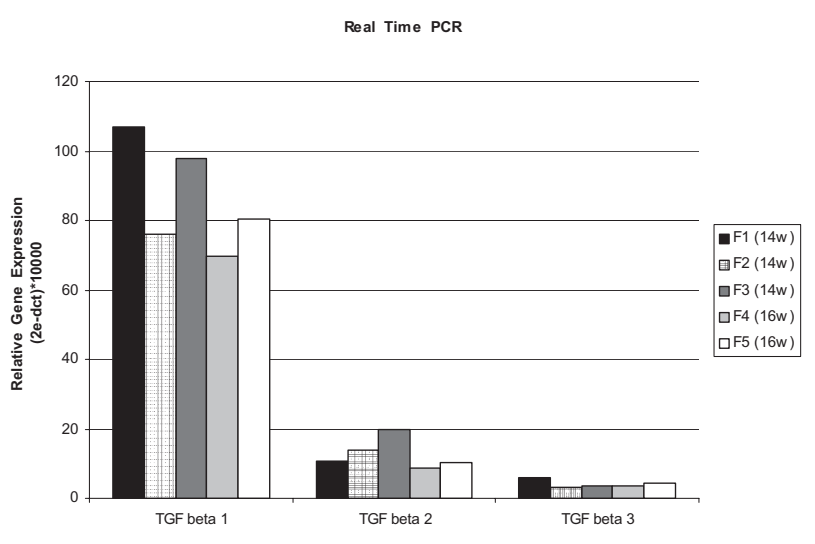

FIG. 3. Expression of TGF- $\beta$ isoform (TGF- $\beta 1$, TGF- $\beta 2$, and TGF- $\beta 3$ ) genes in cell lines that are 14 versus 16 weeks of gestation. Male fetal skin cell lines (three at 14 weeks of gestation [F1-3] and two at 16 weeks [F4 and 5]) were analyzed for isoforms of TGF- $\beta$.

under the same culture conditions for comparison at the same passage numbers. Genes involved in wound healing and those particularly described in fetal wound healing show major differences of expression between fetal and foreskin cells. Three highly homologous TGF- $\beta$ isoforms are known in humans: $\beta 1, \beta 2$, and $\beta 3$ (13). Each form has been found by immunohistochemistry in unwounded fetal skin. However, low levels of TGF- $\beta 1$ and high levels of TGF- $\beta 3$ are expressed at gestational ages associated with scarless repair $(14,15)$.

Exogenous application of TGF- $\beta 1$ to normally scarless fetal wounds resulted in scar formation with an adultlike inflammatory response observed (16). The pro-fibrotic nature of TGF- $\beta 1$, and possibly TGF- $\beta 2$, was confirmed in wounds of adult rats because neutralizing TGF- $\beta 1$ and $\beta 2$ with antibodies partially reduced the amount of scarring (17). However, antifibrotic properties can be seen with the isoform TGF- $\beta 3$ as injection or application of this isoform showed reduced scarring and inflammation in adult wounds $(17,18)$. When using a rabbit hypertrophic scar model, TGF- $\beta 3$ was confirmed to show increased properties in wound healing, but not scar reduction (19). It has been suggested that the relative proportion of TGF- $\beta$ isoforms, and not the absolute concentration of any one isoform, determines the wound repair outcome $(12,14-16)$.

We have seen that TGF- $\beta 2$ was significantly higher in fetal skin dermal fibroblasts than in foreskin tissue fibroblasts, but no major differences with TGF- $\beta 1$ and TGF- $\beta 3$. When looking at expression of the three isoforms in five different fetal skin cell lines, we have observed that TGF- $\beta 1$ gene expression is much higher than that of TGF- $\beta 3$. Importantly, variability between fetal donors for the TGF- $\beta$ isoforms was very small, which is generally the opposite for that of skin from young and old donors. Importance has been given to the TGF- $\beta 3$ isoform by a company in England, Renovo Ltd., which used human recombinant TGF- $\beta 3$ (Juvista) in clinical trials showing 70\% response rate for scar reduction to date.

However, TGF- $\beta 1$ - and $\beta 2$-neutralizing antibodies do not entirely prevent scarring in the adult, and other studies question the efficacy of TGF- $\beta 3$ in wound healing (19).

More recently, inhibition of TGFbRII-mediated signaling was demonstrated with a gene therapy approach in a rabbit hypertrophic scarring model showing some reduction biologically. Lack of complete reduction could either be due to the technical difficulties suggested by the authors for low transduction efficiency, or it may suggest that factors other than TGF- $\beta$ may also be important in scarless repair.

As TGF- $\beta$ 's particular importance in wound healing is also due to their ability to modulate ECM formation, two genes previously shown in wound healing in fetal skin (LAMb1) and in hypertrophic scar (DPT) were analyzed for differences between fetal and foreskin tissue fibroblasts (20). DPT and laminins have important roles in cell-matrix interactions and matrix assembly, and DPT has been shown to be decreased in hypertrophic scar and systemic sclerosis skin fibroblasts (21). No significant differences were seen between fetal cells and foreskin cells for these two selected ECM genes.

As wound healing is very complex, there are certainly many other molecules within the TGF- $\beta$ superfamily which could have a role. For instance, BMP family of genes and their receptors are among those in the TGF- $\beta$ superfamily genes, and have also been strongly associated with cutaneous wound healing and scarless wound healing in the fetus. Over-expression of BMP-6 was shown to delay re-epitheliazation and promote scar formation in a transgenic mouse model (22). BMP-6 is important for maintaining skin homeostasis and is 3.8 times higher expressed in fetal dermal fibroblasts than in foreskin fibroblasts. GDF-10 or BMP-3B seems to be more related to organogenesis and was seen to be 11.8 times less expressed in fetal skin cells.

More recent studies have shown evidence for the importance of angiogenesis and nerve involvement in wound repair $(23,24)$. PTN, a cytokine-inducing heparin-binding/differentiation, is certain to have a major role in angiogenesis in wound healing. MDK and PTN, which have 50\% amino acid sequence identity and striking domain homology, are the two members of the Ptn/Mdk developmental gene family 
(24). In the two nerve growth factor genes studied here, MDK was about 36 times less expressed in fetal skin than in foreskin cells, and PTN was 4.76 times more expressed in foreskin tissue than fetal cells. Interestingly, PTN has been recently shown to induce functional neovasculature in vivo (24). As fetal tissue heals with no inflammatory response, lower MDK and PTN expression is perhaps preferable as it has an important role in angiogenesis.

Overall, we have seen differences between fetal and foreskin dermal fibroblasts in six of nine genes involved in wound healing analyzed by real-time RT-PCR. In a study using Northern analysis to look at gene expression differences between fetal and adult cells, detection was not possible for most growth factors tested. For the TGF isoforms, only TGF- $\beta 1$ was detectable, and no differences were seen between the two cell types similar to what we have seen with fetal and foreskin fibroblasts. Indeed, individual growth factors (TGF- $\beta 2$, TGF- $\beta 3$, IL-10, PDGF) have been shown in the clinic to help in different aspects of overall wound healing, but it is a very complex process $(14,15)$. Most likely, many factors taken together are necessary for complete wound closure which could indeed be offered by a cell-based therapy.

Biological products available for clinical use for wound closure can be divided into either autologous or allogenous, and the advantages and disadvantages of these products are presented in Table 1. As the "gold standard," patient's own skin (often from the scalp for pediatric burns or thighs for ulcers, wounds, and burns) is commonly used as a source of graft material, but this unfortunately creates additional wound sites. At least for burns, skin from related donors such as family members having similar genetic markers has also been used. However, doing so requires the coadministration of powerful immunosuppressant drugs to lessen the patient's immune system so that the graft would not be rejected, but crippling the patient's immune system posing additional, serious problems for the patient. Interestingly, fetal skin cells are preimmunocompetent and associated with a reduced capacity to evoke an immunological response in the recipient of such cells (25).

Described earlier, there are various techniques for cutaneous tissue engineering and skin replacement using different cell sources and delivery systems with varying advantages and disadvantages. For the most part, autologous grafting requires an initial biopsy from the patient, and the cell production processing is cumbersome and long before delivery even with the new methods of "sprayed on skin." Allograft preparations to date require multiple tissue donations, and none of these procedures has been shown to provide full wound closure (Tables 1 and 2) (1,26,27).

Importantly, allografts developed from fetal dermal fibroblast banks associated with a biodegradable collagen matrix show that a biological skin substitute is capable of providing a very high quality of skin repair/replacement in a short period of time with no additional grafting technique necessary ( $48 \mathrm{~h}$ preparation necessary to deliver to patient). It had been shown in other studies that when grafts were prepared with a majority of dermal fibroblasts in proportion to keratinocytes, the stimulation of healing was much greater. The need for dermal components to avoid secondary scar contraction and to assist in a good aesthetical and mechanical result of tissue repair has been well accepted (28). Using only fetal skin fibroblasts, instead of bilayered skin constructs, is therefore a unique and simplified method for providing total wound closure, and thus increases the consistency and safety for the processing of the fetal skin constructs, especially because these cells grow rapidly with only minimal growth requirements, and integrate uniformly and rapidly into a collagen matrix delivery system providing an "off-the-shelf" wound healing construct.

\section{CONCLUSIONS}

Overall, even under the most optimal conditions, adult cutaneous repair necessitates autografting and/or two-step surgical procedures, and ultimately results with scar. Thus, fetal skin represents the ideal paradigm of all tissue repair due to its inherent ability to repair through regeneration rather than scar. Differences of expression in wound healing gene families between fetal cells and other cell types used in biological preparations could be responsible for more efficient repair processes. The results herein lead to the realization that many factors taken together are necessary for complete wound closure which could indeed be offered by a cell-based therapy instead of the delivery of one isolated growth factor. Optimization of the choice of allogeneic cell type and their associated isolation and proliferation consistency along with the specific delivery system will be essential for assuring increasing patients benefiting from tissue engineering in the future.

Acknowledgments: The authors wish to thank Marc-Olivier Montjovent and Dr. Gaël Piquilloud for careful reading of the manuscript. These studies were funded in part by the Braun Foundation and the Foundation for the Orthopedics Hospital of the Swiss Romande. L.A.A. has coauthored a patent pending 
on the use of fetal skin cells for treatment of skin disorders, and participated in a spin-off for the University Hospital.

\section{REFERENCES}

1. Limat A, Mauri D, Hunziker T. Successful treatment of chronic leg ulcers with epidermal equivalents generated from cultured autologous outer root sheath cells. J Invest Dermatol 1996;107:128-35.

2. Kuroyanagi Y, Yamada N, Yamashita R, Uchinuma E. Tissueengineered product: allogeneic cultured dermal substitute composed of spongy collagen with fibroblasts. Artif Organs 2001;25:180-6.

3. Ichioka A, Kouraba S, Sekiya S, Ohura N, Nakatsuka T. Bone marrow-impregnated collagen matrix for wound healing: experimental evaluation in a microcirculatory model of angiogenesis, and clinical experience. Br J Plast Surg 2005;58:112430 .

4. Kaviani A, Perry T, Dzakovic A, Jennings RW, Ziegler MM, Fauza DO. The amniotic fluid as a source of cells for fetal tissue engineering. J Pediatr Surg 2001;36:1662-5.

5. Kaviani A, Perry T, Burnes CM, et al. The placenta as a cell source in fetal tissue engineering. J Pediatr Surg 2002;37:995-9.

6. Jones I, Currie L, Martin R. A guide to biological skin substitutes. Br J Plast Surg 2002;55:185-93.

7. Gallico GG III, O'Connor NE, Compton CC, Remensnyder JP, Kehinde O, Green H. Cultured epithelial auto grafts for giant congenital nevi. Plast Reconstr Surg 1989;84:1-9.

8. Hasegawa T, Suga Y, Mizoguchi M, et al. Clinical trial of allogeneic cultured dermal substitute for the treatment of intractable skin ulcers in 3 patients with recessive dystrophic epidermolysis bullosa. J Am Acad Dermatol 2003;50:803-4.

9. Kashiwa N, Ito O, Ueda T, Kubo K, Matsui H, Kuroyanagi Y. Treatment of full-thickness skin defect with concomitant grafting of 6-fold extended mesh auto-skin and allogeneic cultured dermal substitute. Artif Organs 2004;28:444-50.

10. Hohlfeld J, Roessingh A, Hirt-Burri N, et al. Tissue engineered fetal skin constructs for paediatric burns. Lancet 2005;366: $840-2$.

11. de Buys Roessingh A, Hohlfeld J, Scaletta J, et al. Characterization and use of a fetal skin cell bank for tissue engineering in wound healing. Cell Transplant 2006;15:823-34.

12. $\mathrm{Ng} \mathrm{KW}$, Khor HL, Hutmacher DW. In vitro characterization of natural and synthetic dermal matrices cultured with human dermal fibroblasts. Biomaterials 2004;25:2807-18.

13. Beanes SR, Dang C, Soo C, Ting K. Skin repair and scar formation: the central role of TGF- $\beta$. Expert Rev Mol Med 2003;5:1-11.
14. Bullard KM, Longaker MT, Lorenz HP. Fetal wound healing: current biology. World J Surg 2003;27:54-61.

15. Dang C, Ting K, Soo C, Longaker MT, Lorenz HP. Fetal wound healing. Current perspectives. Clin Plast Surg 2003;30: 13-23.

16. Lin RY, Adzick NS. The role of the fetal fibroblast and transforming growth factor- $\beta$ in a model of human fetal wound repair. Semin Pediatr Surg 1996;5:165-74.

17. Shah M, Foreman DM, Ferguson MWJ. Neutralisation of TGF- $\beta 1$ and TGF- $\beta 2$ or exogenous addition of TGF- $\beta 3$ to cutaneous rat wounds reduces scarring. J Cell Sci 1995;108: 985-1002.

18. Shah M, Foreman DM, Ferguson MW. Control of scarring in adult wounds by neutralising antibody to transforming growth factor $\beta$. Lancet 1992;339:213-4.

19. Wu L, Siddiqui A, Morris DE, Cox DA, Roth SI, Mustoe TA. Transforming growth factor beta 3 (TGF $\beta 3$ ) accelerates wound healing without alteration of scar prominence. Histologic and competitive reverse-transcription-polymerase chain reaction studies. Arch Surg 1997;132:753-60.

20. Okamoto O, Fujiwara S, Abe M, Sato Y. Dermatopontin interacts with transforming growth factor $\beta$ and enhances its biological activity. Biochem J 1999;337:537-41.

21. Kuroda K, Okamoto O, Shinkai H. Dermatopontin expression is decreased in hypertrophic scar and systemic sclerosis skin fibroblasts and is regulated by transforming growth factor- $\beta 1$, interleukin-4, and matrix collagen. J Invest Dermatol 1999;112: 706-10.

22. Kaiser S, Schirmacher P, Philipp A, et al. Induction of bone morphogenic protein-6 in skin wounds. Delayed reepitheliazation and scar formation in BMP-6 overexpressing transgenic mice. J Invest Dermatol 1998;111:1145-52.

23. Stelnicki EJ, Doolabh V, Lee S, et al. Nerve dependency in scarless fetal wound healing. Plast Reconstr Surg 2000;105: 140-7.

24. Christman KL, Fang Q, Kim AJ, et al. Pleiotrophin induces formation of functional neovasculature in vivo. Biochem Biophys Res Commun 2005;332:1146-52.

25. Foglia RP, Dipreta J, Statter MB, Donahoe PK. Fetal allograft survival in immunocompetent recipients is age dependent and organ specific. Ann Surg 1986;204:402-10.

26. Supp DM, Boyce ST. Engineered skin substitutes: practices and potentials. Clin Dermatol 2005;23:403-12.

27. Horch RE, Kopp J, Kneser U, Beier J, Bach AD. Tissue engineering of cultured skin substitutes. Tissue Eng Rev Series 2005;9:592-608.

28. Coulomb B, Friteau L, Baruch J, et al. Advantage of the presence of living dermal fibroblasts within in vitro reconstructed skin for grafting in humans. Plast Reconstr Surg 1998;101: 1891-903. 